University of Nebraska - Lincoln

DigitalCommons@University of Nebraska - Lincoln

Daugherty Water for Food Global Institute:

Faculty Publications

Daugherty Water for Food Global Institute

2021

\title{
Moving beyond 'more crop per drop': insights from two decades of research on agricultural water productivity
}

Meredith Giordano

Susanne M. Scheierling

David O. Tréguer

Hugh Turral

Peter G. McCornick

Follow this and additional works at: https://digitalcommons.unl.edu/wffdocs

Part of the Environmental Health and Protection Commons, Environmental Monitoring Commons, Hydraulic Engineering Commons, Hydrology Commons, Natural Resource Economics Commons, Natural Resources and Conservation Commons, Natural Resources Management and Policy Commons, Sustainability Commons, and the Water Resource Management Commons

This Article is brought to you for free and open access by the Daugherty Water for Food Global Institute at DigitalCommons@University of Nebraska - Lincoln. It has been accepted for inclusion in Daugherty Water for Food Global Institute: Faculty Publications by an authorized administrator of DigitalCommons@University of Nebraska Lincoln. 


\title{
Moving beyond 'more crop per drop': insights from two decades of research on agricultural water productivity
}

\author{
Meredith Giordano ${ }^{a}$, Susanne M. Scheierling ${ }^{b}$, David O. Tréguer ${ }^{a, b}$, Hugh Turralc \\ and Peter G. McCornick ${ }^{d}$
}

a International Water Management Institute (IWMI), Washington, DC, USA; ${ }^{b}$ World Bank, Washington, DC, USA; 'Independent Consultant, Melbourne, VIC, Australia; ${ }^{d}$ Robert B. Daugherty Water for Food Global Institute, University of Nebraska, Lincoln, NE, USA

\begin{abstract}
Concern over increasing water scarcity has led to the introduction of the concept of agricultural water productivity and an emphasis on interventions to achieve 'more crop per drop'. Yet, a strong debate continues on how the concept is to be defined and used. Drawing largely from the irrigation literature, the origins of the concept and its methodological developments are reviewed, and its use in applied work over two decades is discussed. Based on this analysis of conceptual and applied research, key insights into the concept's contributions and limitations are presented, as well as opportunities for further refinements.
\end{abstract}

\section{ARTICLE HISTORY}

Received 17 September 2018 Accepted 24 January 2019

\section{KEYWORDS}

Irrigated agriculture; water scarcity; irrigation efficiency; water productivity; singlefactor productivity; agricultural water management

\section{Introduction}

In 1996, the International Irrigation Management Institute (IIMI) published its first research report, The New Era of Water Resources Management: From 'Dry' to 'Wet' Water Savings (Seckler, 1996). It outlined several key ideas that fundamentally changed the agricultural water management research paradigm from one that focused on 'irrigation efficiency' and 'performance of irrigation systems' to one centred on 'water productivity' and 'river basin management' (Rijsberman, 2006). The report, and the broader focus on water productivity, originated in large part from a concern over increasing water scarcity and longer term trends in water supply and demand. With irrigated agriculture being the largest user of water resources worldwide, there was a need to identify ways to achieve real efficiency gains and real water savings and, thus, 'opportunities for increasing the productivity of water' (Seckler, 1996, p. 10). This idea was later formulated as growing more food with the same or a lesser amount of water, a concept that became popularly known as 'more crop per drop'. For example, in 2000, Kofi Annan, the then United Nations Secretary General, referred to the need for a 'Blue Revolution' in agriculture, focused on increasing productivity per unit of water, or 'more crop per drop' (Annan, 2000, p. 2).

The concept of agricultural water productivity stimulated important conceptual developments in the field of water resources management. It challenged researchers and practitioners to think beyond the traditional notions of 'irrigation efficiency' in the use of irrigation water, 
and consider more broadly the net benefits received in agriculture and other sectors from the use of water. The concept and related terms helped to highlight the importance of scale and the notion of recycling water within a river basin, allowing for a better understanding of whether a 'piecemeal change' (i.e., increasing irrigation efficiency on a farm) represented a real improvement in terms of water saving at the basin scale (Seckler, 1999). Contextual considerations were also emphasized to interpret results and the potential outcomes from water productivity interventions.

The concept of agricultural water productivity continues to gain traction and interest from policy-makers, implementers and the research community. The newly agreed United Nations Sustainable Development Goals (SDGs), and specifically Goal 6.4 that seeks to substantially increase water-use efficiency across all sectors, place the efficient use of water resources on the mainstream development agenda for the first time. Yet, a strong debate and some disagreement continue in the literature on how agricultural water productivity and efficiency terms are to be defined and used (e.g., Frederiksen, Allen, Burt, \& Perry, 2012; Heydari, 2014; Jensen, 2007; Kambou, Xanthoulis, Ouattara, \& Degré, 2014; Pereira, Cordery, \& lacovides, 2012; Perry, Steduto, Allen, \& Burt, 2009; Scheierling \& Tréguer, 2018; Scheierling, Tréguer, \& Booker, 2016; van Halsema \& Vincent, 2012; Wichelns, 2014a).

Through a review and synthesis of two decades of research on water productivity, this paper aims to offer some historical perspective as well as insights to guide the future development and application of appropriate indicators and measures to meaningfully track progress towards the more efficient and productive use of water. The review was carried out in several bibliographic databases using selected research terms, such as water productivity, water efficiency, water accounting, water allocation, and water conservation and savings. We identified more than 500 publications and reports covering the conceptual development of water productivity, its application in different contexts and sectors, impacts on policies and programmes, as well as critiques and alternative concepts and approaches. A significant share of this literature was based on research carried out by the International Water Management Institute (IWMI), formerly the IIMI, and its partners.

Our research emphasizes the evolution and application of the concept of agricultural water productivity, highlighting its contributions and limitations while identifying opportunities for further refinements in the way it is understood and applied. The paper is structured as follows. First, the origins of the concept of water productivity and its methodological developments are reviewed. Second, the use of the concept in applied research is discussed, including the different ways the concept has been operationalized, the main pathways and associated interventions that have been identified for improving water productivity, and the potential contributions to broader development objectives. Third, some key insights from two decades of conceptual and applied research on agricultural water productivity are summarized. We conclude by highlighting how a focus on water productivity has brought greater attention to critical water scarcity and management issues. Important strategic challenges remain, however, for continued improvements in technologies and management practices, data sources, and interdisciplinary research to develop and apply more comprehensive approaches to address water scarcity concerns and, ultimately, make progress towards the broader development objectives. 


\section{Origins of the concept and methodological developments}

IWMI Research Report 1 (Seckler, 1996) introduced the concept of 'water productivity' and related strategies for its improvement to promote real solutions to complex water management problems, including growing demands for, and competition over, scarce water resources, as well as the physical, economic and environmental constraints to developing additional supplies. The report aimed to inspire new and creative concepts that could address key food security and environmental challenges - and thus initiated a 'new era of water management' (Seckler, 1996, p. 3). Seckler (1996) and others (e.g., Keller \& Keller, 1995; Keller, Keller, \& Seckler, 1996) argued that the classical efficiency concepts from the irrigation literature were difficult to apply in the context of mobile resources such as water, and highlighted a need for metrics that account for the capture and reuse of water within larger hydrologic systems, such as river basins.

\section{From irrigation efficiency to agricultural water productivity}

By the early 1990s, a wide body of research from different disciplines - including agronomy, plant physiology and irrigation engineering - already existed on opportunities to increase 'irrigation efficiency' and 'water-use efficiency'. These and related key terms and definitions are presented in Table 1. As a background to the definitions, it is useful to keep in mind the different measures of water quantity (Young, 2005):

Table 1. Key terms and definitions.

Classical irrigation efficiency refers to the ratio of water consumed by crops relative to water applied or, in some instances, relative to water withdrawn from a source. The numerator sometimes takes into account effective precipitation by deducting it from the water consumed. To assess losses in the conveyance and application of irrigation water, the terms conveyance efficiency (the ratio of water received at the farm gate relative to the water withdrawn from the water source) and application efficiency (the ratio of water stored in the root zone and ultimately consumed by crops relative to the water delivered to the farm gate), respectively, are used.

Sources: Israelsen (1932, 1950); Keller \& Keller (1995), Burt et al. (1997), Cai et al. (2006), Jensen (2007)

Water-use efficiency refers to the ratio of plant biomass (or yield) relative to the water consumed (or, in some instances, transpired). In the fields of plant physiology and agronomy, it is typically expressed in kilograms per cubic metre $\left(\mathrm{kg} / \mathrm{m}^{3}\right)$.

Sources: Viets (1962), Molden (1997), Renault and Wallender (2000), Howell (2001), Hsiao et al. (2007), Perry et al. (2009)

Effective irrigation efficiency is defined as the ratio of water consumed, minus effective precipitation, relative to the effective use of water. Effective use of water is the difference between water inflow to an irrigation system and water outflow (with both flows discounted for the leaching requirements to hold soil salinity at an acceptable level). The term was developed to address some of the limitations of classical irrigation efficiency by taking into account the quantity of water delivered from, and returned to, a water supply system (as well as the leaching requirements).

Sources: Keller and Keller (1995), Keller et al. (1996), Cai et al. (2006), Jensen (2007)

Water productivity refers to the ratio of physical production (in terms of biomass or crop yield) or, in some instances, 'economic value' of production (in terms of gross or net value of product) relative to water use (in terms of water withdrawn, applied or consumed). It is, therefore, expressed in kilograms per cubic metre $\left(\mathrm{kg} / \mathrm{m}^{3}\right)$ or US dollars per cubic metre $\left(\mathrm{US} \$ / \mathrm{m}^{3}\right)$. The selection of the numerator and denominator depends on the scale and focus of the analysis.

Sources: Molden (1997), Molden, Sakthivadivel, Perry, de Fraiture, and Kloezen (1998b), Molden and Sakthivadivel (1999), Jensen (2007) 
- Water withdrawal refers to the amount of water removed (or diverted) from a surface water or groundwater source.

- Water application (or delivery) differs from water withdrawal by the amount of water lost in transit from the point of withdrawal to the point of use. This delivery (or conveyance) loss usually stems from leakages, such as from unlined earthen canals.

- Water consumption (or consumptive use, depletion, evapotranspiration) refers to the amount of water that is actually depleted and thus unavailable for further use. In the case of irrigated agriculture, it is the amount transferred to the atmosphere through evaporation from plant and soil surfaces and through transpiration by plants, incorporated into plant products, or otherwise removed from the immediate water environment.

The terms 'efficiency' and 'productivity' are often differently understood in the different disciplines, and also tend to focus on different measures of water. For example, the classical notion of 'irrigation efficiency' was developed in irrigation engineering and commonly measures the ratio of water consumed to water applied or withdrawn from a source. Plant physiologists and agronomists often use the term water-use efficiency and apply different definitions, such as the ratio of plant biomass or yield to transpiration, or the ratio of yield to water consumed (Hsiao, Steduto, \& Fereres, 2007).

A further confounding factor is the range of scales (both spatial and temporal) at which the terms can be defined and applied, for example, from field-scale, seasonal measures of grain biomass per unit of water transpired to basin-scale, annual estimates of the economic value obtained per unit of water applied in the agriculture or other sectors (Bouman, 2007; Kijne, Barker, \& Molden, 2003; Molden et al., 2007b). As stated by Keller and Keller (1995, p. 7):

The classical concepts of irrigation efficiency have been appropriate for farmers making irrigation management decisions and for planners designing irrigation conveyance and application systems. But applying classical efficiency concepts to water basins as a whole leads to incorrect decisions and, therefore, to faulty public policy.

More specifically, Seckler (1996) highlighted three fundamental points: First, classical concepts of irrigation efficiency overlook the fact that so-called 'losses' in water conveyance and application may be reused, or recycled, elsewhere in a river basin. Second, the actual scope for real water savings is often less than imagined because of these recycling opportunities for irrigation water; furthermore, a distinction should be made between real water savings (e.g., due to a reduction in consumptive use) and water reallocation (e.g., when water is redistributed from one user to another). Third, context is important when considering water productivity or, more generally, water management strategies. For example, identifying opportunities to increase water productivity becomes increasingly important in basins with no outflow of usable water; by contrast, in basins with utilizable outflows, other water management objectives may be more appropriate - such as increasing the supply of water to a particular sector, transferring 
water to another basin with more pressing water needs, or reserving water for environmental services.

In line with this thinking, several modifications were proposed to address some of the limitations of the classical efficiency concepts. This included the introduction of the term 'effective irrigation efficiency' to account for leaching requirements and return flows (Keller \& Keller, 1995), and the concept of 'fractions of water use' to break down consumptive and non-consumptive uses and analyze the purposes for which water is consumed (Frederiksen \& Perry, 1995; Molden, 1997; Willardson, Allen, \& Frederiksen, 1994). These refinements to the irrigation efficiency terminology, and the underlying principles, contributed to the conceptual development of 'water productivity'.

Productivity is conventionally understood as a ratio that refers to output per unit of input. Water productivity, in its basic form, measures production per unit of water use. Like land and labour productivity, it is a single-factor productivity metric applied in a multi-factor production process. The denominator, water use, may be measured in terms of water withdrawn, applied or consumed. The numerator can also be expressed in different forms: in the case of physical water productivity, expressed in kilograms per cubic metre of water $\left(\mathrm{kg} / \mathrm{m}^{3}\right)$, the numerator is defined as the physical mass of production (such as biomass or crop yield); in the case of economic water productivity, expressed in US dollars per cubic metre of water $\left(\mathrm{US} \$ / \mathrm{m}^{3}\right)$, the numerator is usually expressed as gross value of output (yield multiplied by price). Other formulations for the numerator have also been used in the literature; an example is water productivity in nutritional terms, expressed in protein grams or kilocalories per cubic metre of water $\left(\mathrm{kcal} / \mathrm{m}^{3}\right)$ (Molden, 1997; Molden \& Sakthivadivel, 1999; Renault \& Wallender, 2000). The water productivity concept is thus applied for different purposes, and at a range of scales - including field, farm, irrigation system or basin.

\section{Water accounting and water productivity indicators}

To consider water productivity better in particular contexts, and help identify strategies for increasing water productivity and achieving real water savings, a framework

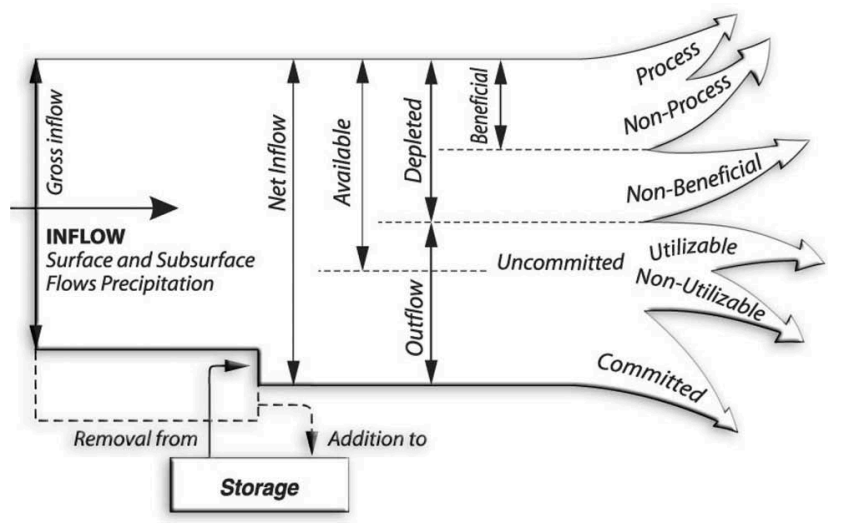

Figure 1. Water-accounting framework.

Source: Adapted from Molden et al. (2003). 
for water accounting was developed. The framework (Figure 1) is based on a water balance approach and a categorization of water (re)uses (Jensen, 2007; Molden, 1997; Molden, El Kady, \& Zhu, 1998a; Molden \& Sakthivadivel, 1999; Perry, 2007). This includes the following:

- Inflow into the domain of interest is expressed as gross inflow (the amount of water flowing in from precipitation and surface and subsurface sources), and net inflow (gross inflow plus any changes in storage).

- Available water is the net inflow less the amount of water set aside for committed outflows (e.g., for downstream water rights and non-utilizable outflows), and includes depleted water and uncommitted utilizable outflows.

- Depleted water includes:

- Beneficial depletion, such as (1) process depletion (for an intended process); in the case of irrigated agriculture, it includes the water transpired by crops and incorporated into plant tissues); and (2) non-process depletion (for a process other than the one for which the diversion was intended); this includes, for example, the water transpired by trees along an irrigation canal; and

- Non-beneficial depletion (such as water flows to sinks).

- Outflow from the domain comprises:

- Uncommitted outflows, both utilizable and non-utilizable (water that is not depleted and in excess of requirements for storage or operational capacity); and

- Committed outflows for other purposes downstream, such as for downstream water rights, minimum streamflows, and offshore fisheries.

The water-accounting framework allows one to show how much water is actually depleted in a given domain, where and for what purpose, compared with what is available. It provides a means to generalize about water productivity, including at different scales - depending on the purpose of the analysis. It can provide first-order estimates of water use within agriculture and across sectors, and give insights into opportunities for real water savings. Some of the framework's advantages are its ability:

- to identify total water depletions (beneficial and non-beneficial);

- to distinguish between process (e.g., agriculture, cities, and industry) and nonprocess (e.g., forests, grassland and water bodies) beneficial depletions;

- to estimate the components of beneficial (either process or non-process) and nonbeneficial (e.g., water flows to sinks) depletions; and

- to account for downstream commitments.

An application of the water-accounting framework is shown in Figure 2, which illustrates the Nile River below the High Aswan Dam, drawing from water-balance studies carried out between 1993 and 1994. In this case, a large proportion of depleted water is used for process depletion, including crop production, and municipal, industrial and navigational uses. A further conversion of the non-beneficial portion of the 


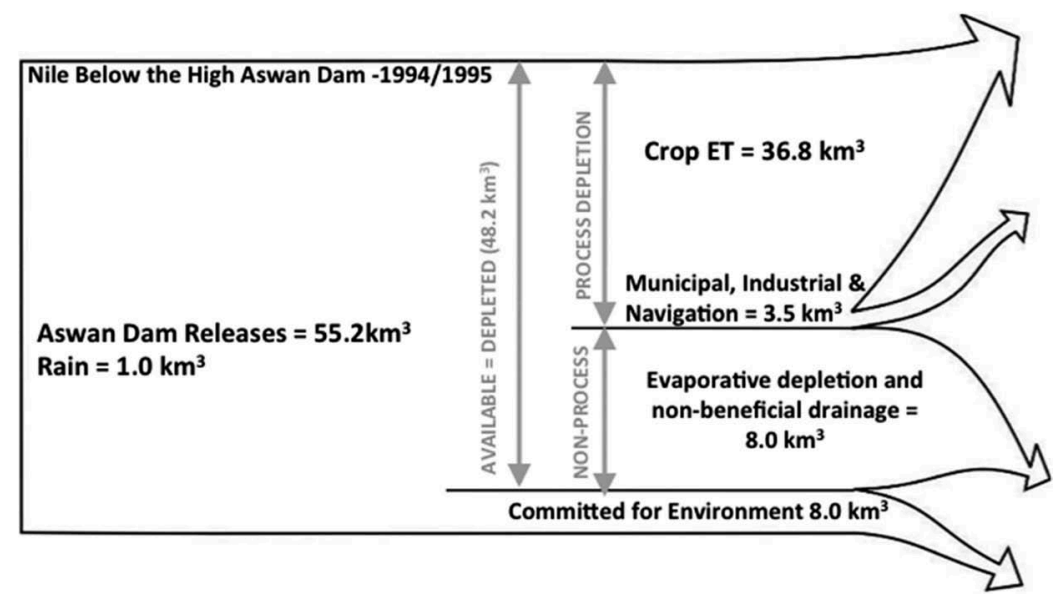

Figure 2. Water-accounting framework for the Nile River below the High Aswan Dam, 1993-94.

Note: ET, evapotranspiration.

Source: Molden and Sakthivadivel (1999).

remaining non-process depletion (non-beneficial drainage in excess of environmental requirements) would allow for improvements in the productivity of water (Molden et al., 1998a).

\section{Beyond 'more crop per drop'}

Early reflections on water productivity highlighted several limitations to restrictive 'crop per drop' interpretations and related performance indicators, and the need for methodological advances to assess the broader implications of improved water productivity, including the associated costs and benefits. Furthermore, restricting the interpretation and application of water productivity to crop outputs ignored important non-crop outputs, such as fisheries, livestock, environmental services and other benefits (and costs) from the use and reuse of water (Rijsberman, 2006). Also, in some circumstances non-process uses, such as environmental services, provided as much or more value than process uses (Murray-Rust \& Turral, 2006; Renault \& Wallender, 2000).

Several studies aimed to identify and, as far as possible, quantify process and nonprocess (net) benefits from the use, and non-use, of water (Bakker, Barker, Meinzen-Dick, \& Konradsen, 1999; Bakker \& Matsuno, 2001; Hussain, Turral, Molden, \& Ahmad, 2007; Meinzen-Dick \& Bakker, 1999, 2001; Meinzen-Dick \& van der Hoek, 2001; Molden et al., 2007b; Renwick, 2001). One of the key findings was that conventional 'crop per drop' indicators of water productivity may not provide reasonable estimates of the overall (net) benefit or value of water - as they do not incorporate the broader uses, and do not account for the direct and indirect costs and benefits at various levels and how these values may vary across time, space and users (Hussain et al., 2007).

Further, while it was often argued that improving water productivity was an inherently good idea, some of the early studies already cautioned against the unreflective use of the concept in terms of 'more crop per drop'. A main reason pointed out was that 
a focus on a single-factor productivity metric in complex agricultural production processes with multiple factors (or inputs) may provide misleading results from the perspective of the farmer as well as the economy as a whole (Barker, Dawe, \& Inocencio, 2003). An example would be extension agents who focus on helping farmers realize potential gains in water productivity (in physical or 'economic' terms) without considering the often significant additional costs involved. Such gains tend to require more labour, better management, new technologies or other additional inputs. Yet, the change in these inputs - together with the related financial and economic costs and benefits - is usually not incorporated into single-factor productivity metrics. A greater understanding of these costs and benefits would be needed to adequately inform policy and investment advice for enhancing water productivity to address broader development objectives (Barker et al., 2003; Kijne, 2003).

These reflections prompted a broadening in the definition of water productivity in irrigated agriculture and related metrics to include a wider perspective on water use, and crop and non-crop and other livelihood and ecological costs and benefits from improving water productivity. Researchers argued that water productivity should be understood in the 'widest possible sense' with the ultimate objective of increasing yields, fisheries, ecosystem services and direct social benefits at less cost (social and ecological) per unit of water consumed (Molden et al., 2010; Rijsberman, 2006).

\section{Applied research}

Over the last two decades, hundreds of publications and reports have been produced that apply water productivity concepts and cover different geographies, contexts and scales. Out of this larger body of research, a selection is discussed below with a focus on three thematic areas: water productivity analysis and mapping; pathways to increase water productivity; and potential contributions to broader development objectives.

\section{Water productivity analysis and mapping}

Water accounting and the related performance indicators presented in the previous section provided a useful framework with which to assess water inflows, uses and outflows across different spatial scales. It helped to overcome some of the limitations of the classical irrigation efficiency concepts, including by incorporating other uses besides crop water use and making more explicit the interactions between different uses, such as agricultural and non-agricultural uses. The framework allowed one to analyze total (beneficial and non-beneficial) water depletion, assess strategies to improve water productivity, identify opportunities for real water savings, and assess the net benefits (in terms of changes in the water productivity indicators) from water reallocation (Murray-Rust \& Turral, 2006).

However, even though the indicators had been kept simple, the availability of primary data, the time and resource challenges to gather additional data, and methodological constraints often hampered their application in field studies (Murray-Rust \& Turral, 2006; Sakthivadivel, de Fraiture, Molden, Perry, \& Kloezen, 1999). Further problems were encountered at larger scales, such as the irrigation system or the basin. To ease these constraints, integrated crop and hydrologic modelling - later in combination with 
remote sensing tools - was increasingly used to simulate the process of water flows and measure water productivity in its various forms at various scales (e.g., Aerts \& Droogers, 2004; Droogers \& Kite, 2001a, 2001b; Ines, Droogers, Makin, \& Das Gupta, 2002; Kite \& Droogers, 2000). Modelling allowed researchers to extrapolate and generate scenarios to complement data derived from field studies. Remote sensing techniques provided important additional data inputs, such as estimates on land use and water consumption, and allowed one to simulate scenarios at multiple spatial and temporal scales and assess water productivity (Karimi, 2014). Remote sensing also contributed to the further development of the water-accounting framework, called Water Accounting Plus (WA+), that allows one to assess not only water flows, stocks and consumption in river basins but also the potential impacts of different water management strategies on, for example, agricultural production and environmental services (Rebelo, 2016).

Over the past two decades, advances in mapping, modelling and remote sensing techniques have eased some of the challenges in assessing water productivity and its variation in different contexts, and also contributed to a better framework for water accounting. Technical and methodological challenges remain, however, including in the accuracy and interpretation of water productivity and accounting measures (Cai et al., 2011; Karimi \& Bastiaanssen, 2015; Karimi et al., 2015; Molden et al., 2010). Moreover, even with these technological advances, water productivity measures on their own do not necessarily provide sufficient information to determine whether increasing water productivity is desirable and, if so, what specific actions need to be taken (Lautze, Cai, \& Matchaya, 2014; Wichelns, 2014a, 2014b). This requires an understanding of different pathways for interventions, the context in which the pathways are introduced, and the related costs and benefits in terms of production, livelihoods and ecological effects. Some of the applied studies have addressed these aspects.

\section{Pathways to increase water productivity}

Four main pathways have been identified for increasing water productivity with different interventions at the scale of the irrigation system or basin (Molden, Murray-Rust, Sakthivadivel, \& Makin, 2003; Molden et al., 2007b; Molden, Sakthivadivel, \& Habib, 2001a): increasing yield per unit of water consumed; reducing non-beneficial depletion; tapping uncommitted flows; and reallocating water among uses. The pathways implicitly target different formulations of water productivity: the first pathway focuses on achieving more yield per unit of water consumed, while the fourth pathway is about increasing water productivity expressed in 'economic' terms (expressed in US\$/ $\mathrm{m}^{3}$ ); the second and third pathways aim to increase the amount of water available for beneficial use. Some research highlights on the four pathways and the related interventions and water productivity indicators are presented below. As will be seen, many studies incorporated elements from more than one pathway to increase water productivity.

\section{Increasing yield per unit of water consumed}

Studies on this pathway discuss as possible interventions management practices for improving the timing of water supplies using supplemental irrigation or deficit irrigation. In dry regions, moisture availability, especially during critical periods, is frequently the most significant factor limiting agricultural production (Hessari, Bruggeman, Akhoond- 
Ali, Oweis, \& Abbasi, 2012; Oweis, Hachum, \& Kijne, 1999). Several longer term studies, conducted in northern Syria, found that rainfall supplemented by irrigation increases water productivity (in terms of yield per unit of water consumed) in wheat systems by alleviating moisture stress during the most sensitive stages of crop growth period (Oweis \& Hachum, 2003; Oweis et al., 1999; Zhang \& Oweis, 1999). Supplemental irrigation combined with deficit irrigation likewise increased water productivity through improved yields, compared with rainfed conditions (Oweis \& Hachum, 2003; Zhang \& Oweis, 1999).

While these cases illustrate the potential for water productivity increases, it is not clear whether these productivity gains in the form of increased yield per unit of water consumed at the field or irrigation system level would translate to increased productivity at the basin scale. Cost and risk considerations would also need to be taken into account (Kijne, 2003). For example, deficit irrigation requires precise management in terms of scheduling water and other inputs, information on rainfall amounts and distribution, and specialized agronomic knowledge on crop water use and crop response to factors such as water deficits, planting dates and nitrogen application (Oweis \& Hachum, 2003).

\section{Reducing non-beneficial depletion}

This pathway involves reducing 'losses' with the aim of generating real water savings (Molden et al., 2003). The related research focused on the introduction of two types of interventions: more capital-intensive technologies, such as sprinkler, drip and other micro-irrigation technologies; and agronomic practices, such as land levelling and zero tillage. While many studies identified a potential to reduce non-beneficial depletion, a recurrent theme has also been the need to consider scale, hydrology and the wider context in the interpretation and potential application of the results. It was often assumed, for example, that micro-irrigation technologies will result in less water consumption than surface irrigation. This is not necessarily the case. Rather, the outcome depends on the biophysical and institutional context as well as the specific technologies and agronomic practices applied and how they are managed (Seckler, 1999; Molden, Sakthivadivel, \& Keller, 2001b; Molden et al., 2007b; Kendy, Molden, Steenhuis, \& Liu, 2003; Kijne, 2003; Ward \& Pulido-Velazquez, 2008; Dagnino \& Ward, 2012; Pfeiffer \& Lin, 2014; Fishman, Devineni, \& Raman, 2015).

Research in the rice-wheat zone of Pakistan's Indus Basin illustrated this point. Ahmad, Masih, Turral, Giordano, and Masood (2006), Ahmad, Giordano, Turral, Masih and Masood (2007a), Ahmad, Turral, Masih, Giordano, and Masood (2007b), and Ahmad, Masih, and Giordano (2014) examined the impact of two 'resource conservation' technologies, laser levelling of fields and zero tillage, on water application, water productivity and real water savings at field, farm and irrigation system level. They showed that, as expected, the introduction of these technologies reduced water applications at the field scale and thus increased water productivity in terms of yield and income per unit of water applied. However, this encouraged farmers with access to fallow land (generally medium- and largescale farmers) to expand their irrigated area. Overall, the increase in field-scale water productivity (in terms of water application) did not result in reduced water use (in terms of consumptive use) at the farm or larger scales. In a different context, where the irrigated area cannot be expanded or where institutional arrangements restrict expansions, for 
example, the outcome would have been different - highlighting the range of factors that may influence the outcomes from water productivity-related interventions.

\section{Tapping uncommitted flows}

In many locations, adding water storage above or below ground is a key intervention to tapping uncommitted flows. Another measure can be replacing surface with groundwater irrigation; studies suggested that this could help increase both physical and 'economic' water productivity, especially if the denominator is expressed in terms of water applied (DebRoy \& Shah, 2003; Shah, 2014). This increase may be the result of several factors, including lower water applications, an associated switch to higher value crops, better timing of the water applications and higher investments in complementary inputs (such as fertilizers and high-yielding seed varieties) given the greater reliability of groundwater (DebRoy \& Shah, 2003).

However, increases in water productivity resulting from tapping uncommitted flows are often associated with significant costs. Depending on the hydrologic context, and the underlying definition of water productivity, costs may also occur in terms of groundwater depletion. An illustration for this is research carried out in the North China Plain, an important agricultural production centre. Since the 1960s, groundwater was the primary source of irrigation water, mainly to supplement unpredictable rainfall patterns. In response to increasing competition for groundwater supplies from industry, the agriculture sector moved toward improving irrigation efficiency (in terms of water application) through the adoption of 'water-saving' technologies. Between the 1970s and 2000, groundwater pumping rates decreased by more than $50 \%$. However, over that same period, groundwater levels continued to decline. This was at least partly due to the local hydrology: The local shallow aquifers are replenished by rainfall and runoff, and depleted by evapotranspiration. If precipitation is higher than evapotranspiration in a given year, runoff and groundwater recharge occurs. If evapotranspiration continually exceeds annual rainfall, which was the case starting from the 1960s, groundwater will be mined. Consequently, while groundwater pumping declined and irrigation efficiency improved, the proportion of groundwater pumped that was consumed by crops increased significantly and return flows to the aquifers declined (Frederiksen et al., 2012; Kendy et al., 2003).

\section{Reallocating water among uses}

One of the interventions to increase 'economic' water productivity (in the conventional definition of gross value of product relative to water applied) is the reallocation of water from lower to higher value uses (Molden et al., 2003; Molle, 2003b). Reallocations can occur within the agricultural sector (e.g., from staple grains to horticulture crops) or across sectors (e.g., from agricultural to the industrial sector).

Reallocating water from agriculture to other sectors is often emphasized as a way of reducing problems of water stress and contributing to broader societal goals. It is seen as a pillar of water demand management, making better use of available resources as opposed to augmenting supplies. Since in many instances irrigation efficiency tends to be low (with a large portion of water withdrawn and applied not consumed by crops), it is commonly believed that improving irrigation efficiency could free up substantial quantities of water for reallocation to other higher value uses. However, given that water used for irrigation is in many instances recycled downstream, the potential savings 
from reallocating agricultural water are often limited and may be problematic when downstream users are affected (Molle, 2003b; Molle \& Berkoff, 2006, 2009; Molle, Wester, Hirsch, Jensen, Murray-Rust, Paranjpye, Pollard \& van der Zaag, 2007; Scott, Silva-Ochoa, Florencio-Cruz, \& Wester, 2001; Wester, Vargas-Velázquez, Mollard, \& Silva-Ochoa, 2008).

The economic gains from intersectoral water reallocations may also not be as high as often expected. For example, if measured in terms of 'economic' water productivity, a comparison of the respective values can be misleading since social, environmental and political costs tend not to be included in the calculations. Such reallocations require value judgments and priority setting to balance different objectives (Barker et al., 2003).

\section{Water productivity and broader development objectives}

Interventions to improve water productivity may seek to contribute to different development objectives. Two key objectives are increasing agricultural production to meet rising food demands and reducing agricultural water use to facilitate reallocations to other sectors. Two additional objectives are raising farm-level income and alleviating poverty and inequity in the agriculture sector. In many instances, water productivity interventions have embraced more than one development objective. Some of the applied research explored the relationship between interventions to increase water productivity and their contribution to the different development objectives

\section{Increasing agricultural production to meet rising food demands}

Concerns over food security and growing water scarcity were at the heart of the call for increased agricultural water productivity in the mid-1990s. Studies showed significant differences in water productivity for various regions of the world, suggesting considerable variations in the scope for raising yield relative to water consumption (Molden et al., 2007b; Sadras \& Angus, 2006).

Yet, the linkages between water productivity and agricultural productivity are not straightforward. While some progress was made in identifying and quantifying the contributions of water and other factors to crop yields, the magnitude of each factor's contribution was found to vary significantly depending on the physical location, the related hydrologic and climatic setting, and other variables (Hussain, Marikar \& Jehanir, 2000; Hussain, Mudasser, Hanjra, Amarasinghe \& Molden, 2004; Hussain, Sakthivadivel, Amarasinghe, Mudasser, \& Molden, 2003; Hussain et al., 2007; Kumar, Sharma, \& Singh, 2009). More fundamentally, the findings impressed the point that farmers' decisions regarding cropping patterns and water use are influenced by a range of context-specific (water- and non-water-related) variables. Thus, a focus on water productivity values in isolation can mask important other variables affecting agricultural production (Lautze et al., 2014). Consequently, policy actions aimed at improving water management for agricultural production need to consider the range of factors and resource constraints that influence farm-level practices and marketing decisions, many of which have no relation to water (Lautze et al., 2014; Wichelns, 2003, 2014b).

\section{Reducing agricultural water use to facilitate reallocations to other sectors}

Increasing agricultural water productivity was also seen as a means to 'save' water for reallocations to other sectors (Molle \& Berkoff, 2006). However, the literature points to 
a rather mixed picture on the linkage between gains in water productivity and the facilitation of reallocations (e.g., Hong et al., 2000; Molle, 2003b; Molle \& Berkoff, 2006; Molle et al., 2007; Scott et al., 2001; Wester et al., 2008). Two cases from the IWMI's research illustrate this point - as well as the importance of clearly defining water productivity and the associated gains.

In the Yangtze River Basin, specifically the Zhanghe Irrigation District in Hubei province, a study explored the impact of water reallocations from irrigated rice to other sectors during the 1990s and early 2000s (Molle \& Berkoff, 2006). They were supported by a suite of complementary technical, managerial and policy interventions. At the farm level, volumetric fees were charged for water supplies, water conservation practices were introduced and ponds were constructed or rehabilitated to capture rainfall and reduce farmers' reliance on reservoir water. At the system level, incentives were put in place to reduce allocations for irrigation while still ensuring sufficient releases to meet food production goals. The study found that despite significant reductions in water releases from the reservoir and associated declines in planted area, rice production did not similarly decline and yields doubled. As a result, water productivity (in terms of yield per unit of water withdrawn from the reservoir) increased significantly. However, as farmers reused drainage water and gained access to alternative water sources (such as farm ponds), water productivity gains may not have been achieved in terms of yield per unit of water consumed (Roost, Cai, Turral, Molden, \& Cui, 2008).

Research carried out in the Liuyuankou Irrigation District located in the Yellow River Basin provides a contrasting case. To meet demands from other sectors, surface water allocations for agriculture were reduced by nearly one-third between 1968 and 2000 (Molle \& Berkoff, 2006). While the objective was also the reallocation of agricultural water, no interventions related to the objective were put in place; notably, no incentives or other mechanisms were provided to restrict groundwater use for agriculture. As a result, while surface water withdrawals for agriculture were reduced, farmers adjusted by pumping additional groundwater (Loeve, Hong, Dong, Mao, Chen, Dave \& Barker, 2004; Molden, Bin, Loeve, Barker, \& Tuong, 2007a).

\section{Raising farm-level income}

A third development objective for increasing water productivity is to raise farm-level income. This may be achieved, for example, by increasing production within a given cropping pattern or by changing the cropping pattern with a move to higher value crops (Molden et al., 2003). Yet, the effects on farm-level income may not be straightforward. For example, a study on the introduction of micro-irrigation technologies (drip and sprinkler systems) in the Indian states of Maharashtra and Gujarat showed that farmers were able to recoup their initial investment within one to three years. The technologies enhanced water productivity (in terms of water applied) as well as the productivity of other agricultural inputs, and reduced the cost of production (Namara, Upadhyay, \& Nagar, 2005). However, while adopters of the micro-irrigation technologies usually reported gains in both yield and profitability, the majority of adopters were wealthier farmers; thus, the poverty impact was not substantial. Moreover, the adopters produced more water-intensive crops than non-adopters and also increased cropping intensity. Similar to the case in the Indus Basin of Pakistan discussed above, the increase in water productivity and farm-level income resulting from the adoption of 'resource 
conserving' technologies was associated with an increasing (rather than decreasing) application of irrigation water.

\section{Alleviating poverty and inequity in the agriculture sector}

A fourth development objective of water productivity-related interventions can be alleviation of poverty and inequities in the agricultural sector. Studies suggested that water productivity and poverty are only weakly linked, and that there is also no clear relationship between poverty and water scarcity within a basin (Fisher, Harding, \& Kemp-Benedict, 2014). Rather, the severity of poverty is more dependent on the level of control than the physical endowment of water (Namara et al., 2010). Stronger linkages also exist between poverty and other factors, such as access to basic services - ranging from safe drinking water and sanitation to healthcare, education, finance and markets (Fisher et al., 2014; Vidal, Harrington, \& Fisher, 2014). Moreover, when relationships were found between the provision of irrigation water and livelihood outcomes, they were closely linked to the level of economic development and institutional factors (Cook, Fisher, Andersson, Rubiano, \& Giordano, 2009; Fisher et al., 2014; Kemp-Benedict et al., 2011; Molle, 2003a). Thus, poverty was found to be more dependent on the stage of a basin's economic and institutional development than the availability of water resources (Cook, Fisher, Tiemann, \& Vidal, 2012; Vidal et al., 2014). Irrigation may play a role in improving livelihood outcomes, but only alongside improvements in other factors, such as access to markets and a supportive institutional environment (Kemp-Benedict et al., 2011).

Complex linkages were also found in relation to inequity; interventions for increasing water productivity could either reinforce or reduce inequities (Clement, Haileslassie, \& Ishaq, 2011a; Clement et al., 2011b; Mapedza et al., 2008). Within a community, the benefits from the introduction of technologies or practices would often benefit some farmers more than others (Ahmad et al., 2007a, 2007b, 2014). Thus, it is important to identify pre-existing inequities in the access to water and other resources among farmers within a community and among communities in order to better target interventions and/or avoid exacerbating inequities (Clement et al., 2011b).

\section{Key insights from two decades of water productivity research}

Since the 1990s, significant conceptual and methodological advancements and insights have emerged from applied research on agricultural water productivity. Through that research, a more nuanced understanding of the concept has also emerged, highlighting its usefulness and limitations, as well as its operationalization and contribution to broader development objectives. Seven key insights are highlighted below.

\section{Key terms need to be properly defined and discussed}

Productivity and efficiency concepts require clear definition when applied to complex problems in water management. Many reports and much of the public debate continues to be vague on the meaning of 'water productivity' and the different notions of efficiency, often using the terms interchangeably - with little discussion about how to define and measure them, what to do to increase them and, importantly, how to 
monitor and assess changes (Scheierling et al., 2016). The terms then become generic to label an array of performance indicators and even development objectives. In part, this is due to the multidisciplinary nature of the topic, with different disciplines using different definitions, and promoting different interventions, with relatively limited exchange between the disciplines. While progress has been made at bridging disciplinary boundaries, further discussion would clearly benefit from more intensive interdisciplinary collaboration and outreach to the general public and decision-makers.

\section{Understanding of the hydrological setting and appropriate scale is critical}

The concept of agricultural water productivity initially evolved as a means of producing more agricultural output with the same amount or less water. A wide range of interventions has been proposed to promote increased water productivity. To understand where and how productivity gains can be made - and possibly also 'real' water savings achieved - requires consideration of the specific hydrological setting, and the appropriate spatial and temporal scale of analysis. With growing water scarcity, the interdependencies among water users increases and gains from the use of water in one location may result in losses in another. Thus, to ensure that a proposed intervention fits the local context and achieves the desired effects requires clear definition of 'water productivity' together with an understanding of the water balance in a given domain (Kendy et al., 2003; Molden et al., 2001b).

\section{Interventions need to be aligned with the objectives and incentives of various decision-makers}

At the policy level, increases in agricultural water productivity are usually called for in connection to the need to meet rising food demand or to reallocate water to other uses. Farmers, though, may be interested in these objectives only insofar as they contribute to maintaining or increasing farm-level income - with water being only one of many often dynamic and context-specific factors affecting crop production and decision-making. Tools are needed to place these different perspectives in context, so that the various factors influencing different users and decision-makers at various levels can be identified and the costs and benefits, and their distribution, from increases in water productivity can be estimated when designing polices or promoting interventions to enhance water productivity.

\section{Well-intended interventions may result in unintended consequences}

Risks and cost considerations for farmers and for society as a whole may go unnoticed in the promotion of water productivity-enhancing practices. Water productivity increases involving higher yields may come in the form of more polluted drainage flows due to farmers' more intensive use of fertilizers and pesticides. Yields (and farm-level incomes) may decrease with interventions that aim at reducing crop consumptive use for 
achieving real water savings, such as deficit or partial irrigation. Further, the adoption of 'water-efficient' technologies and practices involving a switch to higher value crops may increase the exposure to market fluctuations which may disproportionally affect poor farmers because they tend to be less able to cope with or manage risk (van Ittersum et al., 2013). Consequently, unless the possible trade-offs - such as effects on downstream users, increased risk and uncertainty, and rising inequities - are properly incorporated into the assessments, and efforts made to minimize them, changes in water productivity estimates may not be useful to evaluate policy interventions (Bakker et al., 1999; Barker et al., 2003; Kijne, 2003; Wichelns, 2014a, 2014b).

\section{Increasing agricultural water productivity is not a goal in and of itself}

Interventions for water productivity gains should not be seen and pursued in isolation. Rather, they need to be integrated with, and contribute to, one or more of the broader development objectives. Yet, research conducted by the IWMI and others has also suggested that the relationship between water productivity and these objectives is not straightforward, and assessments need to incorporate the trade-offs. For example, in the case of the development objective of increasing agricultural production, it is not clear if a contribution has been made when a water productivity measure increases. The ratio may have improved due to a reduction in water use (however defined) while output remained constant or even decreased. Furthermore, the point of maximum water productivity may be very different from the point of maximum crop yield (Wichelns, 2014a). More complications arise when water productivity estimates are compared over different crop types and over time, and without further information and analysis it is not obvious which situation should be preferred over the other.

\section{Limitations of single-factor productivity metrics must be kept in mind}

Similar to land productivity or labour productivity, water productivity focuses on one factor in a multi-factor, and usually also multi-output, production process. In general, single-factor productivity metrics do not give a full picture of the natural, market or policy context in which agricultural production takes place. For example, water productivity ratios expressed in kilograms per cubic metre or US dollars per cubic metre are often used for making comparisons across users, sectors and over time. It is then important to keep in mind that different water productivity values do not necessarily reflect water-related issues, but may be the result of many other factors and their respective intensity of use, and, depending on the formulation of the ratio, also the result of different outputs and their related prices. Such data can, therefore, provide only an incomplete, and potentially misleading, picture of the underlying drivers of water productivity, especially when used in isolation (Barker et al., 2003; Lautze et al., 2014; Scheierling et al., 2016). On its own, agricultural water productivity may be considered as a weak proxy variable for the objectives that are indeed of interest. However, when considered in context and as part of a larger suite of indicators, measures of water productivity can provide a basis from which to generate and test hypotheses on the underlying causes for the differences and, with further analysis, suggest possible intervention, including at different scales (Cai, Rosegrant, \& Ringler, 2003; Fuglie, 2014). 


\section{New technologies and data sources should be increasingly used and cross-disciplinary approaches promoted}

Tools such as water accounting, hydrologic and crop models, and the data generated with remote sensing technologies have been fundamental to the improvement of the water productivity concept. The development and application of other approaches from related disciplines could also provide new insights and opportunities for improving the definition, assessment and analysis of agricultural water productivity and efficiency. In economics, especially in the field of agricultural production economics, aspects related to productivity and efficiency have been defined and analyzed using more comprehensive approaches, taking into account a range of production factors. Recent surveys of the literature on agricultural productivity and efficiency, which explicitly include water aspects in the measurement of productivity and efficiency, showed that the field offers a number of useful approaches to assess multi-factor production processes (Scheierling \& Tréguer, 2016, 2018; Scheierling et al., 2016). These findings suggest an opportunity to advance economic assessments of water productivity in irrigated agriculture, and to provide insights, in combination with other disciplinary approaches, on how water could be used better in different contexts and in support of different development objectives.

\section{Conclusions}

This paper discussed the concept of agricultural water productivity and its evolution from different efficiency concepts; the development of further indicators to assess and measure change across a range of uses and scales, and their applications; the scope for water productivity gains in different contexts and scales, and the related pathways; as well as the rationale and thinking behind the importance of increasing water productivity, and the contribution to broader development objectives. It highlighted the need for precision in defining water productivity terms, and discussed their limitations. The importance of water accounting as an adaptable framework for estimating water uses and identifying opportunities for improvements has been stressed. Progress in the use of remote sensing to generate additional data for use in water accounting, and in integrated crop and hydrologic modelling, at a range of scales has also been discussed.

In the rich body of literature on agricultural water productivity that has evolved over the past two decades, a shift becomes apparent from more theoretical deliberations (the need to produce more crops with the same or less amount of water) to a more practical discussion (where, why and how to achieve this). Based on the methodological developments and applied research, a number of key insights emerge: scale and context matter, and so do objectives and incentives as well as data and approaches. This body of research suggests that the inherent value of single-factor water productivity metrics may not be as variables to be maximized but rather as initial, albeit imperfect, indicators for regions with increasing water scarcity of the potential for improvements; and as a basis for further analysis of the underlying causes for the differences, the possible interventions - that may or may not be related to water - and their likely impact.

With growing water scarcity in many parts of the world, increases in agricultural water productivity seem to be desirable as a means to reduce overall water use in the 
agriculture sector. However, whether gains in water efficiency or productivity measured as single-factor productivity metrics are a relevant indicator at different scales of analysis and in different settings, or whether they contribute to broader development objectives, depends on a number of complex and interrelated factors, and requires more detailed analysis in those specific settings. The adoption of the SDGs in 2015, with the emphasis on increasing water-use efficiency across all sectors, provides an important moment to revisit the concepts of water efficiency and productivity, their use and limitations, particularly in relation to water savings. The insights of the previous section should be helpful in further operationalizing the implementation of the SDGs.

A further conclusion from two decades of research on water productivity is the need to consider agricultural water productivity as part of a larger suite of metrics and approaches to help address water scarcity concerns and achieve broader development objectives. More intensive interdisciplinary collaboration would help arrive at more comprehensive approaches. Research presented here offers possible entry points with remote sensing, agronomy, hydrology and economic approaches, in particular, from agricultural production economics and irrigation water economics. A focus on water productivity has brought greater attention to water scarcity and management issues and their complexity. There exists now a strategic opportunity to combine the lessons from this large body of research to tackle challenges, improve methods and application, and thus contribute to food and water security, economic growth and poverty-alleviation goals.

\section{Acknowledgments}

This paper is joint work of the International Water Management Institute (IWMI) and the World Bank, and based on an IWMI research report (Giordano, Turral, Scheierling, Tréguer, \& McCornick, 2017) that synthesized work commissioned by the World Bank as part of a study on 'Improving Agricultural Water Productivity and Beyond: What are the Options?' (Scheierling, Tréguer, Booker, \& Decker, 2014). The authors are grateful for the valuable inputs and insights provided by numerous former and current staff of the IWMI, the World Bank, as well as other colleagues. The constructive comments and suggestions received from an editor and a reviewer on an earlier draft are also gratefully acknowledged. The findings, interpretations, and conclusions expressed in this paper do not necessarily reflect the views of the executive directors of the World Bank or the governments they represent. The World Bank does not guarantee the accuracy of the data included in this work.

\section{Disclosure statement}

No potential conflict of interest was reported by the authors.

\section{Funding}

This work was supported by the Water Partnership Program (WPP), a multi-donor trust fund at the World Bank, and the Consultative Group for International Agricultural Research (CGIAR) Research Program on Water, Land and Ecosystems (WLE) with support from CGIAR Fund Donors. 


\section{References}

Aerts, J. C. J. H., \& Droogers, P. (Ed.). (2004). Climate change in contrasting river basins: Adaptation strategies for water, food and environment (pp. 1-273). Wallingford, UK: CABI.

Ahmad, M. D., Giordano, M., Turral, H., Masih, I., \& Masood, Z. (2007a). At what scale does water saving really save water? Lessons from the use of resource conservation technologies in Pakistan. Soil and Water Conservation, 62(2), 29A-35A.

Ahmad, M. D., Masih, I., \& Giordano, M. (2014). Constraints and opportunities for water savings and increasing productivity through Resource Conservation Technologies in Pakistan. Agriculture, Ecosystems \& Environment, 187, 106-115. doi:10.1016/j.agee.2013.07.003

Ahmad, M. D., Masih, I., Turral, H., Giordano, M., \& Masood, Z. (2006, February 22-24). Opportunities and challenges in saving water and improving productivity through resource conservation technologies: Examples from Pakistan. In International Workshop on Water Saving Technologies, Amritsar, Punjab, India (pp. 120-139). New Delhi, India: United States Educational Foundation in India.

Ahmad, M. D., Turral, H., Masih, I., Giordano, M., \& Masood, Z. (2007b). Water saving technologies: Myths and realities revealed in Pakistan's rice-wheat systems (pp. 1-38, IWMI Research Report 108). Colombo, Sri Lanka: International Water Management Institute (IWMI).

Annan, K. (2000). Address of Secretary-General Kofi Annan to the group of 77 developing countries. South Summit, Havana, Cuba, April 12, 2000. Press release SG/SM/7358. New York: United Nations.

Bakker, M., Barker, R., Meinzen-Dick, R., \& Konradsen, F. (Eds.) (1999). Multiple uses of water in irrigated areas: A case study from Sri Lanka (pp. 1-55, SWIM Paper 8). Colombo, Sri Lanka: International Water Management Institute (IWMI).

Bakker, M., \& Matsuno, Y. (2001). A framework for valuing ecological services of irrigation water A case of an irrigation-wetland system in Sri Lanka. Irrigation and Drainage Systems, 15(2), 99-115. doi:10.1023/A:1012933829937

Barker, R., Dawe, D., \& Inocencio, A. (2003). Economics of water productivity in managing water for agriculture. In J. W. Kijne, R. Barker, \& D. Molden (Eds.), Water productivity in agriculture: Limits and opportunities for improvement (pp. 19-35). Wallingford, UK: CABI; Colombo, Sri Lanka: International Water Management Institute (IWMI). (Comprehensive Assessment of Water Management in Agriculture Series 1).

Bouman, B. A. M. (2007). A conceptual framework for the improvement of crop water productivity at different spatial scales. Agricultural Systems, 93(1-3), 43-60. doi:10.1016/j. agsy.2006.04.004

Burt, C. M., Clemmens, A. J., Strelkoff, T. S., Solomon, K. H., Bliesner, R. D., Hardy, L. A., ... Eisenhauer, D. E. (1997). Irrigation performance measures: Efficiency and uniformity. Journal of Irrigation and Drainage Engineering, 123(6), 423-442. doi:10.1061/(ASCE)0733-9437(1997) 123:6(423)

Cai, X. M., Molden, D., Mainuddin, M., Sharma, B., Ahmad, M. D., \& Karimi, P. (2011). Producing more food with less water in a changing world: Assessment of water productivity in 10 major river basins. Water International, 36(1), 42-62. doi:10.1080/02508060.2011.542403

Cai, X. M., Ringler, C., \& Rosegrant, M. W. (2006). Modeling water resources management at the basin level: Methodology and application to the Maipo River Basin (pp. 1-151, IFPRI Research Report 149). Washington, DC: International Food Policy Research Institute (IFPRI).

Cai, X. M., Rosegrant, M. W., \& Ringler, C. (2003). Physical and economic efficiency of water use in the river basin: Implications for efficient water management. Water Resources Research, 39(1), 1013. doi:10.1029/2001WR000748

Clement, F., Haileslassie, A., \& Ishaq, S. (2011a, January 10-14). Intersecting water productivity and poverty: Lessons from the Ganga Basin. Paper presented at the 13th IASC Biennial International Conference on Sustaining Commons: Sustaining Our Future (pp. 1-25). Hyderabad, India.

Clement, F., Haileslassie, A., Ishaq, S., Blümmel, M., Murty, M. V. R., Samad, M., ... Khan, M. A. (2011b). Enhancing water productivity for poverty alleviation: Role of capitals and institutions in the Ganga Basin. Experimental Agriculture, 47(S1), 133-151. doi:10.1017/S0014479710000827 
Cook, S., Fisher, M., Tiemann, T., \& Vidal, A. (2012). Water, food and poverty: Global- and basin-scale analysis. In M. Fisher \& S. Cook (Eds.), Water, food and poverty in river basins: Defining the limits (pp. 239-254). London, UK: Routledge.

Cook, S. E., Fisher, M. J., Andersson, M. S., Rubiano, J., \& Giordano, M. (2009). Water, food and livelihoods in river basins. Water International, 34(1), 13-29. doi:10.1080/ 02508060802673860

Dagnino, M., \& Ward, F. A. (2012). Economics of agricultural water conservation: Empirical analysis and policy implications. International Journal of Water Resources Development, 28(4), 577-600. doi:10.1080/07900627.2012.665801

DebRoy, A., \& Shah, T. (2003). Socio-ecology of groundwater irrigation in India. In R. Llamas \& E. Custodio (Eds.), Intensive use of groundwater: Challenges and opportunities (pp. 307-336). The Netherlands: Swets \& Zetlinger.

Droogers, P., \& Kite, G. (2001a). Estimating productivity of water at different spatial scales using simulation modeling (pp. 1-21, IWMI Research Report 53). Colombo, Sri Lanka: International Water Management Institute (IWMI).

Droogers, P., \& Kite, G. (2001b). Simulation modeling at different scales to evaluate the productivity of water. Physics and Chemistry of the Earth (B), 26(11-12), 877-880. doi:10.1016/S14641909(01)00100-9

Fisher, M., Harding, A., \& Kemp-Benedict, E. (2014). The Challenge Program on Water and Food: A new paradigm for research in the CGIAR. In L. W. Harrington \& M. J. Fisher (Eds.), Water scarcity, livelihoods and food security: Research and innovation for development (pp. 1-14). Oxon, UK: Routledge-Earthscan. (Earthscan Studies in Water Resource Management).

Fishman, R., Devineni, N., \& Raman, S. (2015). Can improved agricultural water use efficiency save India's groundwater? Environmental Research Letters, 10(8), 084022. doi:10.1088/1748-9326/10/ $8 / 084022$

Frederiksen, H. D., Allen, R. G., Burt, C. M., \& Perry, C. (2012). Responses to Gleick et al. (2011), which was itself a response to Frederiksen and Allen (2011). Water International, 37(2), 183-197. doi:10.1080/02508060.2012.666410

Frederiksen, H. D., \& Perry, C. (1995). Needs and priorities in water-related research. Draft paper. Colombo, Sri Lanka: International Irrigation Management Institute (IIMI).

Fuglie, K. O. (2014, December 8-9). Water productivity indicators: What do they tell us? Presentation at Going Beyond Agricultural Water Productivity - International Workshop. Washington, DC: World Bank. Retrieved from http://www.worldbank.org/en/events/2014/11/24/internationalworkshop-going-beyond-agricultural-water-productivity\#2

Giordano, M., Turral, H., Scheierling, S. M., Tréguer, D. O., \& McCornick, P. G. (2017). Beyond 'More Crop per Drop': evolving thinking on agricultural water productivity (pp. 1-53, IWMI Research Report 169). Colombo, Sri Lanka: International Water Management Institute (IWMI); Washington, DC: The World Bank

Hessari, B., Bruggeman, A., Akhoond-Ali, A., Oweis, T., \& Abbasi, F. (2012). Supplemental irrigation potential and impact on downstream flow of Karkheh River Basin of Iran. Hydrology and Earth System Sciences Discussions, 9(12), 13519-13536. doi:10.5194/hessd-9-13519-2012

Heydari, N. (2014). Water productivity in agriculture: Challenges in concepts, terms and values. Irrigation and Drainage, 63(1), 22-28. doi:10.1002/ird.v63.1

Hong, L., Li, Y. H., Deng, L., Chen, C. D., Dawe, D., Loeve, R., \& Barker, R. (2000). Impact of watersaving irrigation techniques in China: Analysis of changes in water allocations and crop production in the Zhanghe Irrigation System and district, 1996 to 1998. In International Water Management Institute (IWMI) Annual Report 1999-2000 (pp. 27-35). Colombo, Sri Lanka: IWMI.

Howell, T. A. (2001). Enhancing water use efficiency in irrigated agriculture. Agronomy Journal, 93 (2), 281-289. doi:10.2134/agronj2001.932281x

Hsiao, T. C., Steduto, P., \& Fereres, E. (2007). A systematic and quantitative approach to improve water use efficiency in agriculture. Irrigation Science, 25(3), 209-231. doi:10.1007/s00271-0070063-2 
Hussain, I., Marikar, F., \& Jehangir, W. (2000). Productivity and performance of irrigated wheat farms across canal commands in the Lower Indus Basin (pp. 1-33, IWMI Research Report 44). Colombo, Sri Lanka: International Water Management Institute (IWMI).

Hussain, I., Mudasser, M., Hanjra, M. A., Amarasinghe, U., \& Molden, D. (2004). Improving wheat productivity in Pakistan: Econometric analysis using panel data from Chaj in the Upper Indus Basin. Water International, 29(2), 189-200. doi:10.1080/02508060408691768

Hussain, I., Sakthivadivel, R., Amarasinghe, U., Mudasser, M., \& Molden, D. (2003). Land and water productivity of wheat in the western Indo-Gangetic Plains of India and Pakistan: A comparative analysis (pp. 1-56, IWMI Research Report 65).Colombo, Sri Lanka: International Water Management Institute (IWMI).

Hussain, I., Turral, H., Molden, D., \& Ahmad, M. D. (2007). Measuring and enhancing the value of agricultural water in irrigated river basins. Irrigation Science, 25(3), 263-282. doi:10.1007/s00271007-0061-4

Ines, A. V. M., Droogers, P., Makin, I. W., \& Das Gupta, A. (2002). Crop growth and soil water balance modeling to explore water management options (pp. 1-26, IWMI Working Paper 22). Colombo, Sri Lanka: International Water Management Institute (IWMI).

Israelsen, O. W. (1932). Irrigation principles and practices (pp. 1-411). New York: Wiley and Sons.

Israelsen, O. W. (1950). Irrigation principles and practices (2nd ed.). New York: John Wiley and Sons, Inc.

Jensen, M. E. (2007). Beyond irrigation efficiency. Irrigation Science, 25(3), 233-245. doi:10.1007/ s00271-007-0060-5

Kambou, D., Xanthoulis, D., Ouattara, K., \& Degré, A. (2014). Water efficiency and productivity concepts: A Review. Biotechnologie Agronomie Societe et Environnement, 18(1), 108-120.

Karimi, P. (2014). Water accounting plus for water resources reporting and river planning (pp. 1-158, PhD thesis). Delft, Netherlands: Delft University of Technology.

Karimi, P., \& Bastiaanssen, W. G. M. (2015). Spatial evapotranspiration, rainfall and land use data in water accounting - Part 1: Review of the accuracy of the remote sensing data. Hydrology and Earth System Sciences, 19, 507-532. doi:10.5194/hess-19-507-2015

Karimi, P., Bastiaanssen, W. G. M., Sood, A., Hoogeveen, J., Peiser, L., Bastidas-Obando, E., \& Dost, R. J. (2015). Spatial evapotranspiration, rainfall and land use data in water accounting Part 2: Reliability of water accounting results for policy decisions in the Awash Basin. Hydrology and Earth System Sciences, 19, 533-550. doi:10.5194/hess-19-533-2015

Keller, A., Keller, J., \& Seckler, D. (1996). Integrated water resource systems: Theory and policy implications (pp. 1-18, IIMI Research Report 3). Colombo, Sri Lanka: International Irrigation Management Institute (IIMI).

Keller, A. A., \& Keller, J. (1995). Effective efficiency: A water use efficiency concept for allocating freshwater resources (pp. 1-19, Winrock International Discussion Paper 22). Arlington, VA: Center for Economic Policy Studies, Winrock International.

Kemp-Benedict, E., Cook, S., Allen, S. L., Vosti, S., Lemoalle, J., Giordano, M., ... Kaczan, D. (2011). Connections between poverty, water and agriculture: Evidence from 10 river basins. Water International, 36(1), 125-140. doi:10.1080/02508060.2011.541015. (Special issue on 'Water, food and poverty in river basins, Part 2: Cross-basin analysis and synthesis').

Kendy, E., Molden, D. J., Steenhuis, T. S., \& Liu, C. (2003). Policies drain the North China Plain: agricultural policy and groundwater depletion in Luancheng County, 1949-2000 (pp. 1-50, IWMI Research Report 71). Colombo, Sri Lanka: International Water Management Institute (IWMI).

Kijne, J. W. (2003). Appendix B. Note on agronomic practices for increasing crop water productivity. In J. W. Kijne, R. Barker, \& D. Molden (Eds.), Water productivity in agriculture: Limits and opportunities for improvement (pp. 319-321). Wallingford, UK: CABI; Colombo, Sri Lanka: International Water Management Institute (IWMI). (Comprehensive Assessment of Water Management in Agriculture Series 1).

Kijne, J. W., Barker, R., \& Molden, D. (2003). Improving water productivity in agriculture: Editors' Overview. In J. W. Kijne, R. Barker, \& D. Molden (Eds.), Water productivity in agriculture: Limits and opportunities for improvement (pp. xi-xix). Wallingford, UK: CABl; Colombo, Sri Lanka: 
International Water Management Institute (IWMI). (Comprehensive Assessment of Water Management in Agriculture Series 1).

Kite, G., \& Droogers, P. (2000). Integrated basin modeling (pp. 1-35, IWMI Research Report 43). Colombo, Sri Lanka: International Water Management Institute (IWMI).

Kumar, M. D., Sharma, B. R., \& Singh, O. P. (2009). Water saving and yield enhancing microirrigation technologies: How far can they contribute to water productivity in Indian agriculture? In U. A. Amarasinghe, T. Shah, \& R. P. S. Malik (Eds.), Strategic analyses of the National River Linking Project (NRLP) of India, Series 1: India's water future: Scenarios and issues (pp. 267-292). Colombo, Sri Lanka: International Water Management Institute (IWMI).

Lautze, J., Cai, X., \& Matchaya, G. (2014). Water productivity. In J. Lautze (Ed.), Key concepts in water resource management: $A$ review and critical evaluation (pp. 57-73). Oxon, UK: Routledge Earthscan.

Loeve, R., Hong, L., Dong, B., Mao, G., Chen, C. D., Dawe, D., \& Barker, R. (2004). Long-term trends in intersectoral water allocation and crop water productivity in Zhanghe and Kaifeng, China. Paddy and Water Environment, 2, 237-245. doi:10.1007/s10333-004-0065-0

Mapedza, E., Amede, T., Geheb, K., Peden, D., Boelee, E., Demissie, T. S., ... Van Koppen, B. (2008). Why gender matters: Reflections from the Livestock-Water Productivity Research Project. In E. Humphreys, R. S. Bayot, M. van Brakel, F. Gichuki, M. Svendsen, P. Wester, ... R. Maclntyre (Eds.), Fighting poverty through sustainable water use: Proceedings of the CGIAR Challenge Program on Water and Food, 2nd International Forum on Water and Food, Addis Ababa, Ethiopia, November 10-14, 2008. Vol. 2. Increasing rainwater productivity; Multi-purpose water systems (pp. 97-100). Colombo, Sri Lanka: CGIAR Challenge Program on Water and Food.

Meinzen-Dick, R., \& Bakker, M. (1999). Irrigation systems as multiple-use commons: Water use in Kirindi Oya, Sri Lanka. Agriculture and Human Values, 16(3), 281-293. doi:10.1023/ A:1007507918459

Meinzen-Dick, R., \& Bakker, M. (2001). Water rights and multiple water uses: Framework and application to Kirindi Oya Irrigation System Sri Lanka. Irrigation and Drainage Systems, 15(2), 129-148. doi:10.1023/A:1012903127115

Meinzen-Dick, R. S., \& van der Hoek, W. (2001). Multiple uses of water in irrigated areas. Irrigation and Drainage Systems, 15(2), 93-98. doi:10.1023/A:1012931726639

Molden, D. (1997). Accounting for water use and productivity (pp. 1-25, SWIM Paper 1). Colombo, Sri Lanka: International Irrigation Management Institute (IIMI).

Molden, D., Bin, D., Loeve, R., Barker, R., \& Tuong, T. P. (2007a). Agricultural water productivity and savings: Policy lessons from two diverse sites in China. Water Policy, 9(S1), 29-44. doi:10.2166/ wp.2007.043

Molden, D., Murray-Rust, H., Sakthivadivel, R., \& Makin, I. (2003). A water-productivity framework for understanding and action. In J. W. Kijne, R. Barker, \& D. Molden (Eds.), Water productivity in agriculture: Limits and opportunities for improvement (pp. 1-18). Wallingford, UK: CABI; Colombo, Sri Lanka: International Water Management Institute (IWMI). (Comprehensive Assessment of Water Management in Agriculture Series 1).

Molden, D., Oweis, T., Steduto, P., Bindraban, P., Hanjra, M. A., \& Kijne, J. (2010). Improving agricultural water productivity: Between optimism and caution. Agricultural Water Management, 97(4), 528-535. doi:10.1016/j.agwat.2009.03.023

Molden, D., Oweis, T. Y., Pasquale, S., Kijne, J. W., Hanjra, M. A., Bindraban, P. S., ... Zwart, S. (2007b). Pathways for increasing agricultural water productivity. In D. Molden (Ed.), Water for food, water for life: A comprehensive assessment of water management in agriculture (pp. 279-310). London, UK: Earthscan; Colombo, Sri Lanka: International Water Management Institute (IWMI).

Molden, D., \& Sakthivadivel, R. (1999). Water accounting to assess use and productivity of water. International Journal of Water Resources Development, 15(1-2), 55-71. doi:10.1080/ 07900629948934

Molden, D., Sakthivadivel, R., \& Habib, Z. (2001a). Basin-level use and productivity of water: Examples from South Asia (pp. 1-29, IWMI Research Report 49). Colombo, Sri Lanka: International Water Management Institute (IWMI). 
Molden, D. J., El Kady, M., \& Zhu, Z. (1998a). Use and productivity of Egypt's Nile water. In J. I. Burns \& S. S. Anderson (Eds.), Contemporary challenges for irrigation and drainage: Proceedings from the USCID 14th Technical Conference on Irrigation, Drainage and Flood Control, Phoenix, Arizona, June 3-6, 1998 (pp. 99-116). Denver, CO: USCID.

Molden, D. J., Sakthivadivel, R., \& Keller, J. (2001b). Hydronomic zones for developing basin water conservation strategies (pp. 1-35, IWMI Research Report 56). Colombo, Sri Lanka: International Water Management Institute (IWMI).

Molden, D. J., Sakthivadivel, R., Perry, C. J., de Fraiture, C., \& Kloezen, W. H. (1998b). Indicators for comparing performance of irrigated agricultural systems (pp. 1-31, IWMI Research Report 20). Colombo, Sri Lanka: International Water Management Institute (IWMI).

Molle, F. (2003a). Development trajectories of river basins: A conceptual framework (pp. 1-37, IWMI Research Report 72). Colombo, Sri Lanka: International Water Management Institute (IWMI).

Molle, F. (2003b). Reform of the Thai irrigation sector: Is there scope for increasing water productivity. In J. W. Kijne, R. Barker, \& D. Molden (Eds.), Water productivity in agriculture: Limits and opportunities for improvement (pp. 273-287). Wallingford, UK: CABl; Colombo, Sri Lanka: International Water Management Institute (IWMI). (Comprehensive Assessment of Water Management in Agriculture Series 1).

Molle, F., \& Berkoff, J. (2006). Cities versus agriculture: Revisiting intersectoral water transfers, potential gains and conflicts (1-70, Comprehensive Assessment of Water Management in Agriculture Research Report 10). Colombo, Sri Lanka: International Water Management Institute (IWMI), Comprehensive Assessment Secretariat.

Molle, F., \& Berkoff, J. (2009). Cities vs. agriculture: A review of intersectoral water re-allocation. Natural Resources Forum, 33, 6-18. doi:10.1111/narf.2009.33.issue-1

Molle, F., Wester, P., Hirsch, P., Jensen, J. R., Murray-Rust, H., Paranjpye, V., ... van der Zaag, P. (2007). River basin development and management. In D. Molden (Ed.), Water for food, water for life: A comprehensive assessment of water management in agriculture (pp. 585-625). London, UK: Earthscan; Colombo, Sri Lanka: International Water Management Institute (IWMI).

Murray-Rust, H., \& Turral, H. (2006). Integrated water resources management. In M. Giordano, F. Rijsberman, \& M. Saleth (Eds.), More crop per drop: Revisiting a research paradigm: Results and synthesis of IWMI's research, 1996-2005 (pp. 22-55). London, UK: IWA Publishing; Colombo, Sri Lanka: International Water Management Institute (IWMI).

Namara, R., Upadhyay, B., \& Nagar, R. K. (2005). Adoption and impacts of microirrigation technologies: Empirical results from selected localities of Maharashtra and Gujarat states of India (pp. 1-47, IWMI Research Report 93). Colombo, Sri Lanka: International Water Management Institute (IWMI).

Namara, R. E., Hanjra, M. A., Castillo, G. E., Ravnborg, H. M., Smith, L., \& van Koppen, B. (2010). Agricultural water management and poverty linkages. Agricultural Water Management, 97(4), 520-527. doi:10.1016/j.agwat.2009.05.007

Oweis, T., Hachum, A., \& Kijne, J. (1999). Water harvesting and supplemental irrigation for improved water use efficiency in dry areas (pp. 1-47, SWIM Paper 7). Colombo, Sri Lanka: International Water Management Institute (IWMI).

Oweis, T. Y., \& Hachum, A. Y. (2003). Improving water productivity in the dry areas of West Asia and North Africa. In J. W. Kijne, R. Barker, \& D. Molden (Eds.), Water productivity in agriculture: Limits and opportunities for improvement (pp. 179-198). Wallingford, UK: CABI; Colombo, Sri Lanka: International Water Management Institute (IWMI). (Comprehensive Assessment of Water Management in Agriculture Series 1).

Pereira, L. S., Cordery, I., \& lacovides, I. (2012). Improved indicators of water use performance and productivity for sustainable water conservation and saving. Agricultural Water Management, 108, 39-51. doi:10.1016/j.agwat.2011.08.022

Perry, C. (2007). Efficient irrigation; inefficient communication; flawed recommendations. Irrigation and Drainage, 56(4), 367-378. doi:10.1002/(ISSN)1531-0361 
Perry, C., Steduto, P., Allen, R. G., \& Burt, C. M. (2009). Increasing productivity in irrigated agriculture: Agronomic constraints and hydrological realities. Agricultural Water Management, 96(11), 1517-1524. doi:10.1016/j.agwat.2009.05.005

Pfeiffer, L., \& Lin, C-Y.C. (2014). Does efficient irrigation technology lead to reduced groundwater extraction? empirical evidence. Journal of Environmental Economics and Management, 67(2), 189-208.

Rebelo, L. M. (2016, September 21-22). The SDGs in practice: Measuring and managing sustainable development water targets. Paper presented at the International Conference on Sustainable Development, New York, USA.

Renault, D., \& Wallender, W. W. (2000). Nutritional water productivity and diets. Agricultural Water Management, 45(3), 275-296. doi:10.1016/S0378-3774(99)00107-9

Renwick, M. E. (2001). Valuing water in irrigated agriculture and reservoir fisheries: A multiple-use irrigation system in Sri Lanka (pp. 1-39, IWMI Research Report 51). Colombo, Sri Lanka: International Water Management Institute (IWMI).

Rijsberman, F. (2006). More crop per drop: Realigning a research paradigm. In M. Giordano, F. Rijsberman, \& M. Saleth (Eds.), More crop per drop: Revisiting a research paradigm: Results and synthesis of IWMI's research, 1996-2005 (pp. 8-21). London, UK: IWA Publishing; Colombo, Sri Lanka: International Water Management Institute (IWMI).

Roost, N., Cai, X. L., Turral, H., Molden, D., \& Cui, Y. L. (2008). Adapting to intersectoral transfers in the Zhanghe Irrigation System, China: Part II: Impacts of in-system storage on water balance and productivity. Agricultural Water Management, 95(6), 685-697. doi:10.1016/j.agwat.2008.01.011

Sadras, V. O., \& Angus, J. F. (2006). Benchmarking water use efficiency of rainfed wheat in dry environments. Australian Journal of Agricultural Research, 57(8), 847-856. doi:10.1071/AR05359

Sakthivadivel, R., de Fraiture, C., Molden, D. J., Perry, C., \& Kloezen, W. (1999). Indicators of land and water productivity in irrigated agriculture. International Journal of Water Resources Development, 15(1-2), 161-179. doi:10.1080/07900629948998

Scheierling, S. M., \& Tréguer, D. O. (2016). Enhancing water productivity in irrigated agriculture in the face of water scarcity. Choices, 31(3), 1-9.

Scheierling, S. M., \& Tréguer, D. O. (2018). Beyond crop per drop. Assessing agricultural water productivity and efficiency in a maturing water economy (pp. 1-74). International Development in Focus. Washington, DC: World Bank Group.

Scheierling, S. M., Tréguer, D. O., \& Booker, J. F. (2016). Water productivity in agriculture: Looking for water in the agricultural productivity and efficiency literature. Water Economics and Policy, 2 (3), 1650007. doi:10.1142/S2382624X16500077

Scheierling, S. M., Tréguer, D. O., Booker, J. F., \& Decker, E. (2014). How to assess agricultural water productivity? Looking for water in the agricultural productivity and efficiency literature (pp. 1-44, World Bank Policy Research Working Paper 6982). Washington, DC: World Bank Group.

Scott, C. A., Silva-Ochoa, P., Florencio-Cruz, V., \& Wester, P. (2001). Competition for water in the Lerma-Chapala Basin: Economic and policy implications of water transfers from agricultural to urban uses. In A. M. Hansen \& M. van Afferden (Eds.), The Lerma-Chapala watershed: Evaluation and management (pp. 291-323). New York, NY: Kluwer Academic.

Seckler, D. (1996). The new era of water resources management: From 'dry' to 'wet' water savings (pp. 1-20, IIMI Research Report 1). Colombo, Sri Lanka: International Irrigation Management Institute (IIMI).

Seckler, D. (1999). Revisiting the 'IWMI paradigm': Increasing the efficiency and productivity of water use (pp. 1-8, IWMI Water Brief 2). Colombo, Sri Lanka: International Water Management Institute (IWMI).

Shah, T. (2014). Groundwater governance and irrigated agriculture (pp. 1-71, TEC Background Papers 19). Stockholm, Sweden: Global Water Partnership, Technical Committee (TEC).

van Halsema, G. E., \& Vincent, L. (2012). Efficiency and productivity terms for water management: A matter of contextual relativism versus general absolutism. Agricultural Water Management, 108, 9-15. doi:10.1016/j.agwat.2011.05.016 
van Ittersum, M. K., Cassman, K. G., Grassini, P., Wolf, J., Tittonell, P., \& Hochman, Z. (2013). Yield gap analysis with local to global relevance - A review. Field Crops Research, 143, 4-17. doi:10.1016/j.fcr.2012.09.009

Vidal, A., Harrington, L. W., \& Fisher, M. (2014). Water scarcity and abundance, water productivity and their relation to poverty. In L. W. Harrington \& M. J. Fisher (Eds.), Water scarcity, livelihoods and food security: Research and innovation for development (pp. 15-44). Oxon, UK: RoutledgeEarthscan. (Earthscan Studies in Water Resource Management).

Viets, F. G., Jr. (1962). Fertilizers and the efficient use of water. In A. G. Norman (Ed.), Advances in Agronomy (Vol. 14, pp. 223-264). New York: Academic Press.

Ward, F. A., \& Pulido-Velazquez, M. (2008). Water conservation in irrigation can increase water use. Proceedings of the National Academy of Sciences of the United States of America, 105(47), 18215-18220. doi:10.1073/pnas.0805554105

Wester, P., Vargas-Velázquez, S., Mollard, E., \& Silva-Ochoa, P. (2008). Negotiating surface water allocations to achieve a soft landing in the closed Lerma-Chapala Basin, Mexico. International Journal of Water Resources Development, 24(2), 275-288. doi:10.1080/07900620701723778

Wichelns, D. (2003). Enhancing water policy discussions by including analysis of non-water inputs and farm-level constraints. Agricultural Water Management, 62(2), 93-103. doi:10.1016/S03783774(03)00079-9

Wichelns, D. (2014a). Do estimates of water productivity enhance understanding of farm-level water management? Water, 6(4), 778-795. doi:10.3390/w6040778

Wichelns, D. (2014b). Investing in small, private irrigation to increase production and enhance livelihoods. Agricultural Water Management, 131, 163-166. doi:10.1016/j.agwat.2013.09.003

Willardson, L. S., Allen, R. G., \& Frederiksen, H. D. (1994, October 19-22). Elimination of irrigation efficiencies: Question 47 - Irrigation planning and management measures in harmony with the environment. Paper presented at the 13th Technical Conference, USCID, Denver, Colorado.

Young, R. A. (2005). Determining the economic value of water: Concepts and methods. Washington, DC: Resources for the Future.

Zhang, H., \& Oweis, T. (1999). Water-yield relations and optimal irrigation scheduling of wheat in the Mediterranean region. Agricultural Water Management, 38(3), 195-211. doi:10.1016/S03783774(98)00069-9 